\title{
The Association of Household Garbage Management and Socioeconomic with Underweight in Children Under Five in Lebak District and Tangerang City, Banten, Indonesia
}

\author{
Noor Edi Widya Sukoco ${ }^{1}$, Yuslely Usman ${ }^{1}$, Gurendro Putro ${ }^{1} \&$ Puti Sari Hidayangsih ${ }^{2}$ \\ ${ }^{1}$ Center of Research for Humanities and Health Management, National Institute of Health Research and \\ Development, Ministry of Health, Jakarta, Indonesia \\ ${ }^{2}$ Center of Research for Public Health Effort, National Institute of Health Research and Development, Ministry of \\ Health, Jakarta, Indonesia \\ Correspondence: Noor Edi Widya Sukoco, Center of Research for Humanities and Health Management, National \\ Institute of Health Research and Development, Ministry of Health, Jalan Percetakan Negara 29, Jakarta, Indonesia. \\ Tel: 62-821-2567-8963.
}

Received: Febary 13, 2021 Accepted: August 10, 2021 Online Published: August 18, 2021

doi:10.5539/gjhs.v13n9p90 URL: https://doi.org/10.5539/gjhs.v13n9p90

\begin{abstract}
Underweight in infants and under-five children may cause growth and developmental disorders and it remains one of the major factors causing child mortality, illness and disability. Underweight is still one of the nutritional problems in Indonesia and the government is undertaking all efforts and drawing up effective strategies to reduce the prevalence of underweight in Indonesia. The purpose of this study was to see what factors were associated with underweight in under-five-year-old children in Lebak Regency and Tangerang City, Banten Province. The study applied the logistic regression method using the 2013 Basic Health Research. Underweight in children was calculated by converting the anthropometric measurements into a standardized value (Z-score), which was then presented in the index of body weight for age. The results obtained among 492 infants revealed there were $28.5 \%$ (about 75 children under five) with underweight status. Children from families who did not apply good sanitation by disposing of garbage in an unsanitary manner had a risk of 15.2 folds $(\mathrm{OR}=15.2,95 \% \mathrm{CI}=4.69-49.65)$ to be underweight compared with those who had good sanitation behaviors. Children under five from families with a low socioeconomic status had a risk of 2.5 folds $(\mathrm{OR}=2.5,95 \% \mathrm{CI}=1.12-5.53)$ to suffer from underweight compared to those who had a high socioeconomic status. The conclusion is sanitation and socioeconomic status are related to the underweight status of children under five in Lebak Regency and Tangerang City.
\end{abstract}

Keywords: children under five, garbage management, socioeconomic status, underweight

\section{Introduction}

Nutrition plays an important role throughout the human life cycle and is critical for both health and economic development. Today, the world faces a double burden of nutrition. In the same country, at the same time, people face the problems of malnutrition. Malnutrition refers to imbalances in a person's intake of energy or nutrients. It includes undernutrition (wasting, stunting, underweight), inadequate vitamins or minerals, overweight, obesity, and diet-related noncommunicable diseases. In fact, 1.9 billion adults are overweight or obese, while at the same time 462 million are underweight, plus 52 million children under five suffer from wasting (WHO, 2019). Around $45 \%$ of deaths among children under 5 years of age are linked to undernutrition (WHO, 2020). Underweight children are those with a low weight-for-age, who may be stunted, wasted, or both. It usually indicates recent and chronic or recurrent undernutrition. Underweight may also be associated with infectious diseases, poor socioeconomic conditions, poor maternal health and nutrition, and/or inappropriate infant and young child feeding and care in early life (Titaley, 2019). Those may increase the risk of death and hold children back from reaching their physical and cognitive potential (Prendergast, 2014; Woldehanna, 2017). This causes underweight as an important indicator that can be used as an initial measure of malnutrition in children.

Based on the results of the 2017 Indonesia Demographic and Health Survey (IDHS), conducted by the National Population and Family Planning Board (NPFPB) and the Central Bureau of Statistics (CBS), Indonesia's overall under-five mortality rate (UMR) remains high, at an estimated 32 deaths per 1000 live births (CBS, 2018). It is far 
from the Sustainable Development Goals (SDGs) target of 25 deaths per 1000 live births (INFID, 2017) and would require extensive efforts from the Government of Indonesia (GOI). The Global Nutrition Report (GNR) 2020 reported that Indonesia is one of the 50 countries that have been on track for 1 target of 4 global nutrition targets (Mannar, 2020). Based on the results of the Basic Health Research (Riskesdas) undertaken by the National Institute of Health Research and Development (NIHRD) - Ministry of Health (MOH), the nutritional status of children has shown improvement. In the case of underweight, the improvement of nutrition is reflected in the reduction of underweight in under-fives from 19.6\% in 2013 to 17.68\% in 2018 (NIHRD, 2013; NIHRD, 2018). Indonesia's national midterm development plan has emphasized the importance of improving the quality of children and improving the quality of the environment in which the two are interconnected (BAPPENAS, 2019). In addition, the main priority of nutrition improvement efforts is the vulnerable group which is infants and children under five (RI, 2009). To improve health and nutrition in children under five, the GOI has implemented several activities, including the Supplementary Feeding for under-fives and Community-Based Total Sanitation activities (MOH, 2019).

A few studies have been conducted to evaluate the association of underweight in children under five and the influencing factors (Putri et al., 2015; Rapar et al., 2014; Nigatu et al., 2018; Tosheno et al., 2017; Adhikari et al., 2017). A quantitative study that examined factors associated with underweight among children under five in Padang found that mother's level of education and working status, as well as the socioeconomic level were significantly related to child underweight (Putri et al., 2015). Other evidence in Manado, North Sulawesi found that maternal parenting was associated with nutritional status of children under five (Rapar et al., 2014). Advanced maternal age (> 35 years), no antenatal care during pregnancy, rural residence (Nigatu et al., 2018), and maternal decision-making power (Tosheno et al., 2017) were found to be significant predictors of underweight children. In addition, there was an association of environmental sanitation and hygiene with underweight in children under five. Research in Nepal found that boiled water drinking practices and growth monitoring were significantly associated with childhood underweight (Adhikari et al., 2017) although the result is still weak.

Given the evidence gap surrounding the effect of sanitation and hygiene behaviour and nutritional status in children under five, this study aimed to see the relationship between underweight and parent's behavior related to sanitation and their socio-economic characteristics using the 2013 Riskesdas. The prevalence of underweight in children under five in Banten Province was 17.2\%, almost the same as the national prevalence in 2013 (19.6\%) (NIHRD, 2013). This shows that the problem of underweight in Banten Province is still a public health problem that needs attention. If seen further, the prevalence of underweight in Lebak Regency reaches $20.8 \%$, which is higher than that of the national average. Meanwhile, the lowest prevalence of underweight in Banten Province is in Tangerang City (10.9\%). Therefore, in this study, the two regions were selected to describe a comparison between those regions with the lowest and highest prevalence rates in Banten Province.

\section{Method}

\subsection{Data Sources}

This study used the data from the 2013 Basic Health Research (Riskesdas), which was carried out simultaneously in 33 provinces throughout Indonesia by the National Institute of Health Research and Development, the Indonesian Ministry of Health.

Riskesdas is a community-based survey conducted by the Ministry of Health to all regions in Indonesia. The purpose of conducting Riskesdas is as a tool to assess the achievement of health development outcomes every five years. Implementation every five years is considered as an actual interval to assess the development of public health status, risk factors and the progress of health development efforts. Data collection methods were undertaken through interviews, measurements, and examinations. Data collection was carried out by local enumerators with technical supervision by the researchers from the National Institute of Health Research and Development, the Ministry of Health, the Republic of Indonesia. In collecting data, 1 team was responsible for 11 to 12 census blocks. The Census Block is an area consisting of 10 households. This means that 1 enumerator team was responsible for 110 to 120 households. A list of census blocks and sample households were obtained from the Central Bureau of Statistics (CBS).

\subsection{Data Collection Tools and Methods}

Data collection began when the enumerator teams had received a copy of the census block list and sample households from CBS. Then, the teams identified the sample locations. Based on the identification, the enumerator teams had an overview of the sample locations so that a data collection schedule plan could be arranged, and the data collection strategies would be carried out to be efficient and effective. 
The interviews used 2 instruments, namely: Household and Individual Questionnaires. The respondents for the Household Questionnaire were heads of families or housewives or household members who could provide information.

The respondents for the Individual Questionnaire comprised of every household member in various age groups. Specifically, for the household members who were less than 15 years old, and in sick condition, interviews were conducted with household members who are their companions.

The anthropometric measurements were carried out using several tools. The height data were measured with a multifunctional height measuring instrument with a measurement capacity of two meters and an accuracy of 0.1 $\mathrm{cm}$. The weight data were measured by a digital scale "Fesco" brand weight, which was calibrated every day. The measurement of abdominal circumference and upper arm circumference used one tool with the brand "Medline". All anthropometric measurements were carried out using measurement guidelines. For blood pressure measurement, a digital "Omron" type IA1 was used, which was required to have its batteries replaced every time one census block had finished. This measurement was performed using the tension measurement guidelines.

Data processing started from editing the questionnaire and coding at the locations of the study conducted by the enumerators. After the questionnaires had been edited and coded correctly, the data were entered into a specified application. After the data were entered, the data were sent via email to the data management team of the National Institute of Health Research and Development for data integration and cleaning. Data cleaning paid attention to inconsistent data and outliers. Inconsistent data and outliers were traced back to the questionnaire to check the truth. The data that had been consistent and free from outliers were then given a weighting value by the Central Bureau of Statistics.

Only data that are clean and weighted by CBS that can be used for analysis. Analysis can use data modification, which is to composite several variables to answer the aim of the study. Variable composites are used for indicators of economic status by 5 quintiles. Indicators are measured through an index that is calculated using Principal Component Analysis (PCA), which is one statistical technique that unites several variables into a single indicator. The PCA method is used to simplify many variables into one by making scores of these variables. The variable scores are formed based on the strength of the correlation between variables.

The Central Bureau of Statistics chose the census block for Riskesdas 2013 based on the 2010 Population Census's frame sampling. The following 12,000 census block lists with 300,000 Census Building lists were completed with the names of the heads of households. The names of the household heads were updated by the enumerators before carrying out the survey. Renewal was intended to update the names of the heads of the households if there was a change, for example whether a household head had moved, died and others.

\subsection{Population and Sample}

The total population in Riskesdas 2013 is all households representing 33 provinces. The sample of households in Riskesdas 2013 was selected based on the 2010 Population Census listing. The household selection process is determined by the Central Bureau of Statistics, which provides a list of selected census buildings originating from the selected census block. Especially for this study, samples are all children under five in Banten Province from Riskesdas data. The unit of analysis of this study is children under five.

\subsection{Variable Measures}

The topic of environmental health in the 2013 Riskesdas aimed to evaluate existing programs, follow up on improvement efforts, and identify environmental risk factors for various types of diseases and health problems. With the environmental health data obtained, it is expected to be used as a basis for policies in an effort to control environmental based diseases.

Environmental health data include drinking water, sanitation (including latrine use and waste management), and housing health. Housing health data include the type of building material, the location of the house and the condition of the house space, the density of the house, the type of fuel for cooking, and the use or storage of pesticides / insecticides and chemical fertilizers in the house. In addition, data on household behavior in draining the bathtub is related to the risk of spreading vector-borne disease (dengue and malaria). Since the unit of analysis is the household, data collection was done by interviews using a household questionnaire and direct observation in the field.

Whereas the specific scope of water includes types of water sources for household and drinking purposes, average water usage per person per day, distance of drinking water sources to feces storage, distance and travel time to drinking water sources, household members who take drinking water, physical quality of drinking water, and 
management (processing and storage) of drinking water. For access to drinking water, the survey referring to the 2006 WHO - Unicef JMP criteria. According to these criteria, households having access to improved drinking water sources are households with drinking water sources from tap water, bore wells / pumps, protected dug wells, springs protected, rainwater and bottled water (ONLY IF the source of water for other household uses is improved).

The scope of sanitation includes the use of defecation facilities, the type of place of defecation, the place of final disposal of feces, the type of waste water collection place, the type of garbage collection place, and the method of waste management. For access to defecation facilities, the 2006 WHO - Unicef JMP criteria were used. According to these criteria, households that have access to improved sanitation facilities are households that use their own open defecation facility, goose neck type for "jamban" or toilet, and landfill septic tank type for feces disposal.

Residential data collected are data on building ownership status, occupancy density, types of building material (ceiling, wall, floor), location of house, condition of house space (cleanliness, presence of windows, ventilation, and natural lighting), use of fuel for cooking, household behavior in draining the bathtub, and storing dangerous and toxic materials such as pesticides or insecticides and chemical fertilizers in the house.

Types of fuel use in households according to the Decree of the Minister of Health of the Republic of Indonesia, the types of fuel are grouped into two, which are "safe" meaning it does not have the potential to cause pollution (electricity and gas / LPG) and "unsafe" meaning it has the potential to cause pollution (kerosene, charcoal and firewood).

The dependent variable analyzed was underweight indicators (Index of Weight for Age). While the independent variables analyzed were age and sex of children under five, education and work status of father and mother, family socioeconomic status, the immunization status of children under five, presence of health facility, and environmental health aspects such as access to clean water and handling of family waste.

To assess the nutritional status of children under five, the body weight and age (in month) of each child under five was converted into a standardized value (Z-score) using the anthropometric standard WHO 2005. Furthermore, based on the Z-score the following restrictions were determined:

Classification of nutritional status based on Weight for Age index:

Severe Underweight: Z-score $<-3.0$

Underweight: Z-score $\geq-3.0$ to $Z$-score $<-2.0$

Good Nutrition: Z-score $\geq-2.0$

Regarding literature, the independent variables having associations with underweight are sex of children under five, age in month, education and work status of father and mother, family socioeconomic status, the immunization status of children under five, presence of health facility, and environmental health aspects such as access to clean water and handling of family waste.

Age variables were divided between two categories which were below 24 months and above 24 months. While education level of parents was divided into two categories as well, below junior high school and above senior high school. Thus, working status of parents was also categorized as working and not working. Meanwhile, children's immunization status was classified into completed and not completed. And, the presence of health facility was characterized as present and none. Then, access to clean water was considered easy when it was inside the house or affordable fast and difficult when it was outside the house or far away. While waste management was labelled as poor when it was dumped into the river or littered garbage, and good as it was handling by officers or made to composting.

\subsection{Statistical Analysis}

The data were coded and analyzed using SPSS version 15 package. This study adopted two ways of analyzing the data. Initially, the proportion of underweight, socio-demographic characteristics, immunization, availability of health care facilities, drinking water access and household waste management were evaluated. Missing data is not estimated. These factors were assessed using Pearson's chi-square test in bivariate analysis. Any potential confounders and explanatory variables that were significant at the 0.25 level based on the Wald test were retained and entered into the multivariate logistic regression model in the second step. In this step, the Enter method is used. Results from the regression analysis are presented as $\operatorname{Exp}(\mathrm{B})$ with $95 \%$ confidence intervals (CI) respectively. Sample weights were used to adjust for differences in the probability of selection between students (Kleinbaum, 1988). 


\section{Results}

From the total samples of children in Banten Province out of 518 children under five, 6 children had to be eliminated because of incomplete data characteristics of children (age and anthropometric data), so the total samples were 512 children. Of these, 255 children were from Lebak District and 257 children were from Tangerang City. Besides, at the time of analysis, the authors excluded children who were overweight, so the total samples analyzed were 492 children under five, which includes normal weight.

As may be seen in Table 1 below there are $28.5 \%$ of children under five in Lebak Regency who are underweight, while in Tangerang City all children under five have a good nutritional status.

Table 1. Distribution of underweight and the social demographic characteristics of children under five in Lebak and Tangerang

\begin{tabular}{|c|c|c|c|c|c|c|c|}
\hline \multirow[t]{3}{*}{ No. } & \multirow[t]{3}{*}{ Variable } & \multicolumn{6}{|c|}{ Children under five $(\mathrm{N}=492)$} \\
\hline & & \multicolumn{2}{|c|}{ Underweight } & \multicolumn{2}{|c|}{ Normal } & \multicolumn{2}{|c|}{ Total } \\
\hline & & $\overline{\mathbf{N}}$ & $\%$ & $\mathbf{N}$ & $\%$ & $\mathbf{N}$ & $\%$ \\
\hline \multirow[t]{3}{*}{1} & Regency/city & & & & & & \\
\hline & Lebak & 75 & 28.5 & 188 & 71.5 & 263 & 100.0 \\
\hline & Tangerang & 0 & 0.0 & 229 & 100.0 & 229 & 100.0 \\
\hline \multirow[t]{3}{*}{2} & Sex of children & & & & & & \\
\hline & Boys & 34 & 12.5 & 237 & 87.5 & 271 & 100.0 \\
\hline & Girls & 40 & 18.2 & 180 & 81.8 & 220 & 100.0 \\
\hline \multirow[t]{6}{*}{3} & Age of children & & & & & & \\
\hline & $0-11$ months & 19 & 21.6 & 69 & 78.4 & 88 & 100.0 \\
\hline & $12-23$ months & 12 & 12.5 & 84 & 87.5 & 96 & 100.0 \\
\hline & 24-35 months & 16 & 17.4 & 76 & 82.6 & 92 & 100.0 \\
\hline & $36-47$ months & 13 & 12.9 & 88 & 87.1 & 101 & 100.0 \\
\hline & 48-59 months & 15 & 13.0 & 100 & 87.0 & 115 & 100.0 \\
\hline
\end{tabular}

From Table 1, the percentage of underweight in infants (aged below 12 months) is $21.6 \%$. This condition causes infants to become susceptible to infectious diseases and thus should obtain more attention. Based on the gender characteristics of children under five, it may be seen that there are more females with less nutritional status than males.

Table 2. The relationship between health services, environmental factors and socio-economic status with underweight in children under five in Lebak and Tangerang

\begin{tabular}{|c|c|c|c|c|c|c|}
\hline \multirow{3}{*}{ No. } & \multirow{3}{*}{ Variable } & \multicolumn{5}{|c|}{ Children under five } \\
\hline & & \multicolumn{2}{|c|}{ Underweight } & \multicolumn{2}{|c|}{ Normal } & \multirow[t]{2}{*}{ P value } \\
\hline & & $\overline{\mathbf{N}}$ & $\%$ & $\mathbf{N}$ & $\%$ & \\
\hline \multirow[t]{3}{*}{1.} & Completed immunization & & & & & \\
\hline & Not completed / never & 58 & 14.2 & 350 & 85.8 & 0.162 \\
\hline & Completed & 17 & 20.2 & 67 & 79.8 & \\
\hline \multirow[t]{3}{*}{2.} & The existence of health facilities & & & & & \\
\hline & None & 0 & 0 & 2 & 100 & 0.548 \\
\hline & Present & 75 & 15.3 & 415 & 84.7 & \\
\hline \multirow[t]{3}{*}{3.} & Easy access to water & & & & & \\
\hline & Difficult & 35 & 16.7 & 174 & 83.3 & 0.426 \\
\hline & Easy & 40 & 14.1 & 243 & 85.9 & \\
\hline
\end{tabular}


4. Garbage management

Poor (dumped in river, etc)

Good (handling by officers, made compost)

$72 \quad 25.7$

$\begin{array}{lll}208 & 74.3 & 0.000\end{array}$

Father's education

Low ( = Junior high school)

$3 \quad 1.4$

20998.6

High ( =Senior high school)

$\begin{array}{ll}60 & 19.9\end{array}$

$\begin{array}{lll}241 & 80.1 & 0.000\end{array}$

Mother's education

Low ( = Junior high school)

$15 \quad 7.9$

$176 \quad 92.1$

High ( =Senior high school)

$\begin{array}{ll}60 & 18.8\end{array}$

$\begin{array}{lll}259 & 81.2 & 0.003\end{array}$

$\begin{array}{ll}15 & 8.7\end{array}$

$158 \quad 91.3$

7. Father's job

Not worked

$\begin{array}{lllll}5 & 29.5 & 12 & 70.6 & 0.198\end{array}$

Work

$\begin{array}{llll}64 & 17.2 & 308 & 82.8\end{array}$

8. Mother's job

$\begin{array}{llllll}\text { Not worked } & 10 & 10.4 & 86 & 89.6 & 0.094 \\ \text { Work } & 61 & 17.5 & 288 & 82.5 & \end{array}$

9. Economic status

$\begin{array}{llllll}\text { Poor (Q1-Q2) } & 43 & 38.7 & 68 & 61.3 & 0.000 \\ \text { Rich (Q3-Q5) } & 31 & 8.2 & 349 & 91.8\end{array}$

From Table 2 it is known that children under five who had immunization would have a good nutritional status, compared with those who did not obtain immunization. Families who had access to clean water would have a good nutritional status than those who did not.

Table 2 shows parents who had a low education level had a statistically significant relationship with underweight in children under five. Likewise, in the group of father who did not work, then the proportion of underweight children would be higher compared to working father group. Household in quintile 1-3 which sometimes may be assumed as poor household, has related to higher proportion of underweight children.

Table 3. Multivariable determinant factors associated with underweight in children under five

\begin{tabular}{|c|c|c|c|c|c|c|c|c|}
\hline & \multirow{2}{*}{ B } & \multirow{2}{*}{ S.E. } & \multirow{2}{*}{ Wald } & \multirow{2}{*}{ df } & \multirow{2}{*}{ Sig. } & \multirow{2}{*}{$\operatorname{Exp}(B)$} & \multicolumn{2}{|c|}{ 95\% C.I.for EXP(B) } \\
\hline & & & & & & & Lower & Upper \\
\hline Completed immunization & -.265 & .389 & .464 & 1 & .496 & .767 & .358 & 1.645 \\
\hline \multirow{2}{*}{\multicolumn{9}{|c|}{$\begin{array}{l}\text { 0. Not completed/ never } \\
\text { 1. Completed }\end{array}$}} \\
\hline & & & & & & & & \\
\hline Garbage management & 2.726 & .602 & 20.517 & 1 & .000 & 15.267 & 4.694 & 49.656 \\
\hline \multicolumn{9}{|l|}{ 0. $\quad \mathrm{Bad}$} \\
\hline \multicolumn{9}{|l|}{ 1. Good } \\
\hline Father's education & .876 & .549 & 2.548 & 1 & .110 & 2.401 & .819 & 7.037 \\
\hline \multicolumn{9}{|l|}{ 0. Low } \\
\hline \multicolumn{9}{|l|}{ 1. High } \\
\hline Mother's education & -.717 & .581 & 1.525 & 1 & .217 & .488 & .156 & 1.524 \\
\hline \multicolumn{9}{|l|}{ 0. Low } \\
\hline \multicolumn{9}{|l|}{ 1. High } \\
\hline Father's job & 1.019 & .707 & 2.078 & 1 & .149 & 2.771 & .693 & 11.076 \\
\hline 0. Jobless & & & & & & & & \\
\hline 1. Had a job & & & & & & & & \\
\hline
\end{tabular}




\begin{tabular}{|c|c|c|c|c|c|c|c|c|}
\hline $\begin{array}{l}\text { Mother's job } \\
0 . \quad \text { Jobless } \\
\text { 1. } \quad \text { Had a job }\end{array}$ & .089 & .446 & .040 & 1 & .842 & 1.093 & .456 & 2.618 \\
\hline \begin{tabular}{ll}
\multicolumn{2}{l}{ Economic level } \\
0. & Q1-3 (poor) \\
1. & Q4-5 (Rich)
\end{tabular} & .912 & .407 & 5.024 & 1 & .025 & 2.491 & 1.121 & 5.531 \\
\hline Constant & -.447 & .812 & .303 & 1 & .582 & .639 & & \\
\hline
\end{tabular}

From Table 3, there is a significant relationship between environmental health and socioeconomic status with the nutritional status of children.

Table 3 shows children who live in households that are good in handling household waste are up to 15 times more likely to have a normal weight compared to children who live in households with poor waste management $(\mathrm{OR}=15.267 ; 95 \% \mathrm{CI}=4.69-49.66)$. Likewise, under-fives from families with middle to upper socioeconomic levels have a 2.49 times chance of not being underweight compared to children with low socioeconomic status $(\mathrm{OR}=2.49 ; 95 \% \mathrm{CI}=1.12-5.53)$.

\section{Discussion}

Those analyses show there is a relationship between environmental factors and the nutritional status of children, in this case, the behavior of disposing garbage with underweight in children under five. Unsanitary behavior such as disposing garbage into the river will increase the risk factors of vector-borne diseases such as diarrhea, cholera, or typhoid. Theoretically, this can be explained that re-current episodes of diarrhea and the likelihood of tropical or environmental enteropathy (where fecal contamination causes changes in the intestine that affect permeability and absorption) may inhibit the absorption of nutrients resulting in malnutrition. Improving water, sanitation, and hygiene, as well as housing and access to health services, will promote a healthy environment, will reduce the prevalence of infectious diseases and may affect the decreasing prevalence of malnutrition (UNICEF, 2015). The same results of the relationship between environmental factors and nutritional status of children under five were also found in the study of Manzomi et al and Kwami et al in 2019. Manzomi in Cambodia found that the composite of several factors of water, sanitation and hygiene (WASH) had a relationship with the prevalence of wasting and stunting. Types of water source and types of toilet are examples of environmental factors associated with the prevalence of malnutrition. While Kwami in Ethiopia examined the relationship between WASH and stunting, they found environmental factors, such as the behavior of the caregiver's handwashing and drinking water facilities had a close relationship with stunting (Manzoni et al., 2019; Kwani et al., 2019).

Underweight cases in children under five in Banten Province are quite similar to the study in Indonesia which was undertaken by Setyawati et al (2015). They reported a quite similar analysis result where garbage management has related to underweight. Setyawati has catagorized garbage management as good if garbage is collected and carried by officers or buried in the ground to be made into compost, as well as the analysis in Banten (Setyawati et al., 2015). One thing that should be noted is that Setyawati et. al. analyzed the 2013 Riskesdas data throughout Indonesia with the multi-level analysis method, while the analysis in this article only discusses Banten Province with logistic regression analysis method.

In addition to the environment, the results of this study also show the relationship between socioeconomic factors and underweight status in children under five. The lower the socioeconomic status is, the worse the children's nutritional status will be. This is closely related to the ability and purchasing power of the family. This is in line with the results reported by Santi et al (2012) in South Bengkulu that the higher the family income level is, the better the children's nutritional status will be (Santi et al., 2012). Several studies in other parts of Indonesia and abroad showed similar results of the relationship between poverty and malnutrition (Saputra et al., 2012; Suarni et al., 2016; Indarti, 2016; Chirwa et al., 2008; Busse et al., 2018; Abera et al., 2019). For example, studies in Malawi and Ethiopia report something similar to our results that children who come from economically capable households, in this case those having jobs or earning a living, tend to be more nutritious (Chirwa et al., 2008; Busse et al., 2018).

The relationship between economic status and nutritional status of children under five was also found in a study conducted by Titaley et al. In their publications, they describe the close relationship between the household wealth index and stunting. The wealth index is a composite of several variables of ownership or assets in the household, which is generally used to assess food security (Titaley, 2019). 
Titaley et al also found a relationship between newborn weight and the nutritional status of children under five. The risk of stunting increases if children experienced low birth weight (LBW) at birth $(<2500$ grams). These findings are in line with several other studies in Indonesia (Rahayu et al., 2015; Dewi \& Widari, 2018). Meanwhile, a study in Central Sulawesi reported that there was a significant relationship between LBW and the management of burned waste. Babies born in households that have a habit of burning garbage are born with LBW ( $<2500$ grams) (Hidayangsih et al., 2014). This finding is also supported by a study in Ghana-Africa which indicated that babies born to mothers who reported burning waste in their homes during pregnancy had an increased risk of low birth weight (Amegah et al., 2012). This can be explained because garbage burning relates to dioxins, carbon monoxide (CO) and some particulates (PM) into the air. If humans inhale these harmful substances it would impair fetal growth. CO blends with hemoglobin to penetrate the placenta and reducing oxygen supply which limits the ability of the placenta to transfer nutrients to the fetus. PM decreases the lung function of the baby's mother and consequently reduces oxygen delivery to the fetus and causes cell damage. Fetal growth disorders may lead to an increased risk of LBW (Washam, 2018; Mishra, 2004; Smith et al., 2003). This finding requires further research to explain the relationship between waste management, the risk of LBW and then the nutritional status of children under five at the end.

\section{Conclusion}

Sanitation associated with waste management has a significant relationship with the prevalence of malnutrition in children under five. Unhealthy waste disposal, in this case incinerated, has the risk of causing malnutrition. In addition, the results of this study also found that socioeconomic status was associated with under-nutrition status in children under five. Poor families are at higher risk of experiencing poor nutritional status.

Parents must maintain a healthy home environment by managing their domestic waste disposal properly. Education on the importance of maintaining environmental sanitation and hygiene remains necessary.

The low socioeconomic level of the family may lead to reduce nutritional intake which in turn affects the nutritional status of children under five. Multi-sector collaboration and interdisciplinary interventions between nutrition and health, environment and economic sectors are recommended to address the problem of under-five nutrition in poor families.

\section{Acknowledgments}

The authors would like to express gratitude to the Head of Center of Research for Humanities and Health Management who gave the opportunity to do the research, Professor Dr. Dede Anwar Musadad, SKM, M.Kes and Dra. Athena Anwar, MSi for their insights in writing this manuscript.

\section{Competing Interests Statement}

The authors declare that there are no competing or potential conflicts of interest.

\section{References}

Abera, S. F., Kantelhardt, E. J., Bezabih, A. M., Gebru, A. A., Ejeta, G., Lauvai, J., ... \& Scherbaum, V. (2019). Nutrition-specific and sensitive drivers of poor child nutrition in Kilte Awlaelo-Health and Demographic Surveillance Site, Tigray, Northern Ethiopia: implications for public health nutrition in resource-poor settings. Global health action, 12(1), 1556572. https://doi.org/10.1080/16549716.2018.1556572

Adhikari, D., Khatri, R. B., Paudel, Y. R., \& Poudyal, A. K. (2017). Factors associated with underweight among under-five children in eastern Nepal: community-based cross-sectional study. Frontiers in Public Health, 5 , 350.

Amegah, A. K., Jaakkola, J. J., Quansah, R., Norgbe, G. K., \& Dzodzomenyo, M. (2012). Cooking fuel choices and garbage burning practices as determinants of birth weight: a cross-sectional study in Accra, Ghana. Environmental Health, 11(1), 1-10. https://doi.org/10.1186/1476-069X-11-78

Bappenas. (2019). Technocratic Draft National Mid-Term Development Plan 2020 - 2024: Prosperous, Fair and Sustainable Medium-High Income Indonesia. Ministry of PPN/ Bappenas. Jakarta, Indonesia; Retrieved 2020, Jul 21, from https://www.bappenas.go.id/files/rpjmn/Narasi RPJMN IV 2020-2024_Revisi 28Juni2019.pdf (In Indonesian)

Busse, H., Jogo, W., Leverson, G., Asfaw, F., \& Tesfay, H. (2018). Prevalence and predictors of stunting and underweight among children under 5 years in Tigray, Ethiopia: implications for nutrition-sensitive agricultural interventions. Journal of Hunger \& Environmental Nutrition, 13(4), 435-454. https://doi.org/10.1080/19320248.2017.1393364 
Central Bureau of Statistic. (2018). Under-Five Mortality Rate Per 1000 Live Births by Province, 2012 and 2017 [Internet] (p. 3-4.). Badan Pusat Statistika. Retrieved Jul 21, 2021, from https://www.bps.go.id/dynamictable/2018/06/06/1464/angka-kematian-neonatal-akn-dan-angka-kematian-b ayi-per-1000-kelahiran-menurut-provinsi-2012.html (In Indonesian)

Chirwa, E. W., \& Ngalawa, H. P. (2008). Determinants of child nutrition in Malawi. South African Journal of Economics, 76(4), 628-640. https://doi.org/10.1111/j.1813-6982.2008.00212.x

Dewi, N. T., \& Widari, D. (2018). The Relationship Between Low Birth Weight and Infection Disease with Stunting among Children Under Two Years of Age in at Maron Kidul Village Maron Subdistrict in Probolinggo District. Amerta Nutr, 373-381. (In Indonesian). https://doi.org/10.2473/amnt.v2i4.2018.373-381

Hidayangsih, P. S., Tjandrarini, D. H., Kristanto, A. Y., \& Sukoco, N. E. W. (2014). Disposal of household burned garbage and risk of low birth weight in Central Sulawesi Province, Indonesia. Health Science Journal of Indonesia, 5(2), 89-93.

Indarti, Y. (2016). Relationship between Family Economic Status and Nutritional Status of Toddlers in Ajung District, Jember Regency in 2016. J Fenom, 15(1), 150-62. (In Indonesian). Retrieved from ejournal.iain-jember.ac.id/index.php/fenomena/article/view/559

INFID. (2017). Sustainable Development Goals: Goal 03. International NGO Forum on Indonesian Development. Retrieved from https://www.sdg2030indonesia.org/page/11-tujuan-tiga

Kleinbaum, D. G., Kupper, L. L., \& Muller, K. E. (1988). Applied regression analysis and other multivariable methods Boston (2nd ed.). Duxbury Press.

Kwami, C. S., Godfrey, S., Gavilan, H., Lakhanpaul, M., \& Parikh, P. (2019). Water, sanitation, and hygiene: Linkages with stunting in rural Ethiopia. Int $J$ Environ Res Public Health, 16(20). Retrieved from https://www.researchgate.net/publication/336398708_Water_Sanitation_and_Hygiene_Linkages_with_Stun ting_in_Rural_Ethiopia

Mannar, M. G. V., \& Micha, D. R. (2020). Global Nutrition Report: Action on equity to end malnutrition. Bristol, UK. Retrieved from https://globalnutritionreport.org/reports/2020-global-nutrition-report/appendix3-countries-on-track-2025-global-nutrition-targets/

Manzoni, G., Laillou, A., Samnang, C., \& Hong, R. (2019 ). Child-Sensitive WASH Composite Score and the Nutritional Status in Cambodian Children. Retrieved from https:/www.researchgate.net/publication/335693040_Child-Sensitive_WASH_Composite_Score_and_the_ Nutritional_Status_in_Cambodian_Children

Ministry of Health. (2019). Ministry of Health Improves Community Nutrition Status [Internet]. Kementerian Kesehatan Republik Indonesia. (In Indonesian). Retrieved from https:/www.kemkes.go.id/article/view/19081600004/kemenkes-tingkatkan-status-gizi-masyarakat.html

Mishra, V. (2004). What do we know about health effect of smoke from solid fuels combustion? East-West Center working papers. Population and health series, 117, 1-40.

Nigatu, G., Woreta, S. A., Akalu, T. Y., \& Yenit, M. K. (2018). Prevalence and associated factors of underweight among children 6-59 months of age in Takusa district, Northwest Ethiopia. International journal for equity in health, 17(1), 1-8.

NIHRD. (2013). Basic Health Research. Jakarta, Indonesia: Ministry of Health. Retrieved Nov 27, 2015, from https://www.litbang.kemkes.go.id/laporan-riset-kesehatan-dasar-riskesdas/

NIHRD. (2018). Basic Health Research. Jakarta, Indonesia: Ministry of Health. Retrieved Jul 21, 2020, from, https:/www.litbang.kemkes.go.id/laporan-riset-kesehatan-dasar-riskesdas/. (In Indonesian)

Prendergast, A. J., \& Humphrey, J. H. (2014). The stunting syndrome in developing countries. Paediatrics and international child health, 34(4), 250-265. https://doi.org/10.1179/2046905514Y.0000000158

Putri RF, Sulastri D, Lestari Y. (2015). Factors Related to the Nutritional Status of Children in the Work Area of the Nanggalo Padang Health Center. $J$ Kesehat Andalas, 4(1), 254-61. Retrieved from http://jurnal.fk.unand.ac.id/index.php/jka/article/view/231/225

Rahayu, A., Yulidasari, F., Putri, A. O., \& Rahman, F. (2015). Birth Weight Records with Stunting Incidence among Children under Two Years Old. Kesmas-National Public Health Journal, 10(2), 67-73. (In 
Indonesian). https://doi.org/10.21109/kesmas.v10i2.882

Rapar, V. L., Rompas, S., \& Ismanto, A. Y. (2014). The Relationship between Mother's Parenting Pattern and Children Nutrition Status in the Work Area of Ranotana Weru Public Health Center, Wanea District, Manado $\begin{array}{lllll}\text { City. } & J & \text { Keperawatan, } & \text { Retrieved } & \text { from }\end{array}$ https://ejournal.unsrat.ac.id/index.php/jkp/article/view/5228/4742

Republic of Indonesia. (2009). Republic of Indonesia Law No. 36 of 2009 concerning Health (p. 1-48). House of Representative of Indonesia Republic. Jakarta. Retrieved from https:/www.hukumonline.com/pusatdata/detail/lt4af3c27570c04/undangundang-nomor-36-tahun-2009

Santi, D. Y., Utama, S. P., \& Putranto, A. M. H. (2012). The Relationship Between Socio-Economic Conditions and Environmental Sanitation Hygiene and Nutritional Status of Children 2-5 Years Old in Seginim District, South Bengkulu Regency. Natural Resource Management and Environment Researcher, 1(2), 141-6. (In Indonesian). Retrieved from http://repository.unib.ac.id/407/1/DEBBY YURIKE SANTI-1.pdf

Saputra, W., \& Nurrizka, R. H. (2012). Demographic and Risk Factors for Malnutrition and Undernutrition. Makara Kesehat, 16(2), 95-101. Retrieved from http://journal.ui.ac.id/index.php/health/article/viewFile/1636/1366 (In Indonesian).

Setyawati, B., Pradono, J., \& Rachmalina, R. (2015). The Role of Individuals, Households and Basic Health Services on Malnutrition Status in Toddlers in Indonesia. Health Research and Development Media, 25(4), 227-34. Retrieved from http://ejournal.litbang.kemkes.go.id/index.php/MPK/article/view/4589

Smith, K. R., Mehta, S., \& Maeusezahl-Feuz, M. (2003). Indoor air pollution from household use of solid fuels. Comparative quantification of health risks: global and regional burden of disease attributable to selected major risk factors, 2, 1435-1493.

Suarni, K. A. (2016). Relationship between Family Socio-Economic Status and Nutritional Status of Toddlers at Batua Health Center Makassar. J Science of Health Diagnosis, 9(2), 165-9. (In Indonesian). Retrieved from https://jurnalstikesnh.files.wordpress.com/2016/10/165169.pdf

Titaley, C. R., Ariawan, I., Hapsari, D., Muasyaroh, A., \& Dibley, M. J. (2019). Determinants of the stunting of children under two years old in Indonesia: a multilevel analysis of the 2013 Indonesia basic health survey. Nutrients, 11(5), 1106. https://doi.org/10.3390/nu11051106

Tosheno, D., Mehretie Adinew, Y., Thangavel, T., \& Bitew Workie, S. (2017). Risk factors of underweight in children aged 6-59 months in Ethiopia. Journal of nutrition and metabolism, 2017. https://doi.org/10.1155/2017/6368746

UNICEF. (2015). UNICEF Data: Monitoring the situation of children and women "Undernutrion contributes to nearly half of all deaths in children under 5 and is widespread in Asia and Africa". UNICEF. Retrieved from https://data.unicef.org/topic/nutrition

Washam, C. (2008). Cooking with wood may fuel birth weight. Kitchen smoke puts babies at risk. Environ Health Perspect, 106, 61-66.

World Health Organization [WHO]. (2019). Nutrition: Malnutrition is a world health crisis. Retrieved July 21, 2020, from https://www.who.int/nutrition/topics/world-food-day-2019-malnutrition-world-health-crisis/en/

World Health Organization [WHO]. (2020). Malnutrition-A Fact Sheet. Retrieved July 21, 2020, from https:/www.who.int/news-room/fact-sheets/detail/malnutrition

Woldehanna, T., Behrman, J. R., \& Araya, M. W. (2017). The effect of early childhood stunting on children's cognitive achievements: Evidence from young lives Ethiopia. Ethiopian Journal of Health Development, $31(2), 75-84$.

\section{Copyrights}

Copyright for this article is retained by the author(s), with first publication rights granted to the journal.

This is an open-access article distributed under the terms and conditions of the Creative Commons Attribution license (http://creativecommons.org/licenses/by/4.0/). 